\title{
The influence of dietary inclusion of wood vinegar supplementation on growth performance, nutrient digestibility, and meat quality in grower-finisher pigs
}

\author{
Shanmugam Sureshkumar, Vetriselvi Sampath and In Ho Kim ${ }^{\varpi}$ \\ Department of Animal Resource and Science, Dankook University, No. 29 Anseodong, Cheonan, Choongnam, 330-714, South Korea
}

The current research aimed to evaluate the effects of dietary inclusion of wood vinegar on growth performance, nutrient digestibility, and meat quality of grower-finisher pigs. In total, 132 crossbred (\{Landrace $\times$ Yorkshire $\times$ Duroc $\}$ ) grower-finisher pigs with an initial average body weight $30.48 \pm 4.23 \mathrm{~kg}$ (11 replications/treatment; 4 pigs/pen) were used in a 16-week trial. Based on the body weight and sex the pigs were randomly assigned to three treatments. Dietary treatments consisted of the basal diet (CON) or the basal diet supplemented with $0.05 \%$ and $0.1 \%$ wood vinegar. The inclusion of dietary wood vinegar supplementation significantly improved the body weight gain (BWG) and average daily gain (ADG) $(P=0.0521 ; 0.043)$ of pigs at week 16 . The total track nutrient digestibility of dry matter and nitrogen was linearly increased in pigs fed with an increased amount of wood vinegar. In addition, dietary supplementation of wood vinegar linearly improved longissimus muscle area, yellowness ( $\left.b^{*}\right)$ of the meat color, and carcass weight $(P<0.05)$ and a tendency in linear reduction was observed for water holding capacity $(P=0.068)$, and drip loss at d5 and d7 $(P=0.091,0.069)$. However, there was no significant difference found for lean meat percentage and backfat thickness in this experiment. In summary, dietary inclusion of wood vinegar supplementation enhanced growth performance and total track digestibility of nutrients and had no effects on lean meat percentage and backfat thickness of grower-finisher pigs.

Keywords: wood vinegar, grower-finisher pigs, nutrient digestibility, meat quality, growth performance

Received: 05 December, 2020; revised: 03 March, 2021; accepted: 16 March, 2021; available on-line: 11 May, 2021

『e-mail: inhokim@dankook.ac.k

Acknowledgements of Financial Support: The present research was supported by the research fund of Dankook University in 2020.

Abbreviations: BW, body weight; ADG, average daily gain; ADFI, average daily feed intake, G; F, gain to feed ratio; DM, dry matter; $\mathrm{N}$, nitrogen; BFT, backfat thickness; LMP, lean meat percentage; AGP, antibiotic growth promoters; WHC, water-holding capacity

\section{INTRODUCTION}

Antibiotics, as growth promoters and therapeutic compounds, are widely used to decrease the susceptibility to infectious diseases, and have been employed in animal production for several years (Barton, 2000). Nevertheless, widespread concern about the use of antibiotics in animals has risen in recent years owing to the appearance of antibiotic-resistant bacteria that could pose a danger to human health (Huang et al., 2010). The use of antibiotics as growth promoters in animal feed has been prohibited in South Korea since 2011 (Global Agricultural Information Network, 2011). Therefore, it has become mandatory to develop antibiotic-free diets for domestic animals including swine (Bae et al., 1999) and thus, an immense effort has been made towards the identification of the alternatives to antibiotics as growth promoters in the livestock industry (Hong et al., 2004; Cho et al., 2006). Consequently, several alternatives such as probiotics, prebiotics, organic acids, phytogenics and so on are used as a substitute for antibiotic growth promoters (AGP). Wood vinegar is obtained from the distillation of smoke from burning wood and is a complex mixture of water and organic compounds. Moreover, wood vinegar contains phenolic compounds similar to catechols, guaiacols, and organic acids such as acetic, propionic, and formic acid (Mohan et al., 2006; Cai et al., 2012). Previously, Wang et al. (2012) stated that the presence of acetic acid and phenolic compounds in wood vinegar could have an anti-germination effect. Moreover, Samanya and Yamauchi (2001) stated that dietary supplementation of wood vinegar enhanced the feed efficiency and intestinal morphology of villus height and crypt depth in chickens. Similarly, Mekbungwan and others (Mekbungwan et al., 2004) and Choi and others (Choi et al., 2009) stated that $0.3 \%$ wood vinegar supplementation improved growth performance and apparent total digestibility of weaning pigs during the overall experiment. However, to date, the literature on the application of wood vinegar in growerfinisher pigs is still limited. Therefore, the aim of this research was to evaluate the efficacy of wood vinegar on growth performance, nutrient digestibility, and meat quality of grower-finisher pigs.

\section{MATERIALS AND METHODS}

The described protocol (Approval No: DK-2-2204) was permitted and pigs were maintained according to the guidelines of the Animal Care and Use Committee of Dankook University, Republic of Korea.

\section{Sources of wood vinegar}

Wood vinegar used in the present study was obtained from Chumdan Environment Co. Ltd, Republic of Korea. The Quercus acutissima plants were burned at 550$650^{\circ} \mathrm{C}$ then the smoke was cooled by a water-cooling system and distilled. It was stored for 6 months. Then the filtrate solution was distilled to remove harmful substances, the supernatant was collected and purified to use for the experiment. Wood vinegar composition con- 
tained $10.97 \%$ propionic compound and 3.89\% acetic acid as analyzed by Korea Chemistry Association.

\section{Trial design and diet}

A total of 132 mixed-sex Landrace $\times$ Yorkshire $\times$ Duroc $\}$ grower-finisher pigs with an initial average body weight of $30.48 \pm 4.23 \mathrm{~kg}$ (Mean \pm S.E.) were used in a 16-week experimental trial. At first, grower-finisher pigs were randomly divided according to their initial body weight and sex (4 pigs ( 2 gilts and 2 barrows) per pen). Thirty-three pens were randomly allotted to 3 treatments, where each pen was counted as one replication and each treatment had 11 replications. The treatments were as follows: basal diet (Control), the basal diet with $0.05 \%$ and $0.1 \%$ wood vinegar. The dietary treatments were based on a corn-wheat-soybean meal diet formulated as per the recommendation of the National Research Council (2012) (Table 1). The pigs were housed at a thermostatically controlled ambient environmental temperature $\left(25^{\circ} \mathrm{C}\right)$ on a slatted plastic floor, and every pig was individually identified using tags. The pigs had access to feed and water ad libitum, through a self-feeder and nipple drinker, respectively.

\section{Sampling and laboratory analysis}

Individual pigs body weight (BW) was measured at the start of the experiment, in week 4 and week 16 to determine the daily gain (ADG). In addition, the consumption of feed and leftovers was calculated on pen basis during the whole experimental period to determine the average daily feed intake (ADFI) and gain to feed ratio (G: F). In order to measure the total tract digestibility of dry matter (DM), nitrogen $(\mathrm{N})$, and energy, $0.20 \%$ chromium oxide was added to the diet as an indigestible marker 7 days prior to fecal collection at end of the experiment. Feed and fecal samples were collected randomly from at least 2 pigs (1 barrow and 1gilt) per pen then homogenized well and stored in a freezer at $-20^{\circ} \mathrm{C}$. All feed and fecal samples were freeze-dried and finely ground to pass through a $1 \mathrm{~mm}$ screen. DM and $\mathrm{N}$ digestibility was determined using methods established by the Association of Official Analytical Chemists (AOAC, 2000). Chromium absorption was determined by UV absorption spectrophotometry (UV-1201, Shimadzu, Kyoto, Japan). The energy was measured by the heat combustion of the samples using Parr 6100 oxygen bomb calorimeter (Parr Instrument Co., Moline, IL, USA). The apparent total tract digestibility was calculated using the following formula: digestibility $(\%)=\{1-[(\mathrm{Nf} \times \mathrm{Cd}) /$ $(\mathrm{Nd} \times \mathrm{Cf})]\} \times 100$, where $\mathrm{Nf}=$ nutrient concentration in faeces $(\% \mathrm{DM}), \mathrm{Nd}=$ nutrient concentration in diet $(\%$ $\mathrm{DM}), \mathrm{Cd}=$ chromium concentration in $\operatorname{diet}(\% \mathrm{DM})$, and $\mathrm{Cf}=$ chromium concentration in faeces $(\% \mathrm{DM})$.

Backfat thickness and lean meat percentage were assessed at the beginning and at the end of the experiment. Backfat thickness was measured using Pig-log 105 (Carometec Food Technology, Denmark) at the P2 position $(6.5 \mathrm{~cm}$ area on the right and left end frames). To determine the quality of pork meat 2 pigs (per pen) were slaughtered by exsanguinations and evisceration at a local commercial slaughterhouse. $30 \mathrm{~min}$ after death pork muscle was collected and stored at $-4^{\circ} \mathrm{C}$ for further analysis. Lean meat samples were thawed at room temperature prior to evaluation. According to the protocols of the National Pork Producers Council (NPPC) the meat color, marbling and firmness scores were determined. To detect lightness, redness, and yellowness values each sample (surface) was measured at 3 locations using CR-
Table 1. Ingredients and chemical composition of the complete diet ( $\mathbf{g} / \mathbf{k g}$, as fed basis).

\begin{tabular}{|c|c|c|}
\hline Ingredient & Grower & Finisher \\
\hline Corn & 474 & 566.3 \\
\hline Wheat & 30 & 20 \\
\hline Molasses & 40 & 40 \\
\hline Wheat bran & 30 & - \\
\hline Corn gluten feed & 19 & 20 \\
\hline Soybean meal & 306 & 249 \\
\hline Rapeseed meal & 20 & 20 \\
\hline Corn germ meal & - & 10 \\
\hline Lysine (80\%) & 1 & 0.6 \\
\hline Methionine (99\%) & 0.4 & - \\
\hline Tallow (liquid) & 50 & 46 \\
\hline Limestone & 9.3 & 12.3 \\
\hline Di-calcium Phosphate & 15.6 & 11.3 \\
\hline Salt & 2 & 2 \\
\hline Vitamin premix ${ }^{1}$ & 1.5 & 1.5 \\
\hline Mineral premix ${ }^{2}$ & 1 & 1 \\
\hline \multicolumn{3}{|l|}{ Calculated composition } \\
\hline Crude protein & 194.1 & 171.2 \\
\hline Crude fat & 76.3 & 74.1 \\
\hline Crude fiber & 31.0 & 27.6 \\
\hline Crude ash & 58.1 & 53.2 \\
\hline Calcium & 8.0 & 8.0 \\
\hline Total phosphorus & 6.0 & 5.0 \\
\hline Available phosphorus & 3.5 & 2.7 \\
\hline Total lysine & 11.3 & 9.5 \\
\hline Methionine & 3.5 & 2.8 \\
\hline Available methionine & 3.1 & 2.5 \\
\hline \multicolumn{3}{|l|}{ Analyzed composition } \\
\hline Metabolize energy, $\mathrm{MJ} / \mathrm{kg}$ & 13.21 & 13.80 \\
\hline Crude protein & 195.6 & 170.5 \\
\hline Crude fat & 76 & 73.2 \\
\hline Crude fiber & 32.3 & 27.9 \\
\hline Crude ash & 58.5 & 53.1 \\
\hline Calcium & 8.1 & 8.0 \\
\hline Total phosphorus & 5.9 & 5.1 \\
\hline Total lysine & 11.8 & 9.8 \\
\hline Methionine & 3.7 & 2.9 \\
\hline
\end{tabular}

1Provided per kilogram of complete diet: $1.3 \mathrm{mg}$ of Vitamin A (Retinol); $0.022 \mathrm{mg}$ of Vitamin $\mathrm{D}_{3}$ (Cholecalciferol); $45 \mathrm{mg}$ Vitamin $\mathrm{E}$ (Tocotrienol); $4.2 \mathrm{mg}$ Vitamin $\mathrm{K}_{3}$ (Menodione); $24.6 \mathrm{mg}$ Vitamin $\mathrm{B}_{5}$ (d-Ca-pantothenate); $8.6 \mathrm{mg}$ Vitamin B2 (Riboflavin); and $0.04 \mathrm{mg}$ Vitamin $\mathrm{B}_{12}$ (Cobalamins). 2Provided per kilogram of complete diet: $15 \mathrm{mg} \mathrm{Cu} ; 80 \mathrm{mg} \mathrm{Fe} ; 56 \mathrm{mg} \mathrm{Zn}$; 73 mg Mn; 0.3 mg I; 0.5 mg Co; 0.4 mg Se.

410 Chromameter (Konica Minolta Sensing Inc., Osaka, Japan). The $\mathrm{pH}$ of muscle was measured $24 \mathrm{~h}$ after postmortem using a pH meter (Testo 205, Testo, Germany). The water-holding capacity (WHC) was determined following the method of Kauffman and others (Kauffman et al., 1986). In brief, a $0.3 \mathrm{~g}$ pork meat sample was kept 
Table 2. Effects of dietary inclusion of wood vinegar on growth performance of grower-finisher pigs.

\begin{tabular}{|c|c|c|c|c|c|c|}
\hline \multirow{2}{*}{ Item } & \multicolumn{3}{|c|}{ Wood vinegar (\%) } & \multirow{2}{*}{ S.E.M. ${ }^{1}$} & \multicolumn{2}{|c|}{$P$-value ${ }^{2}$} \\
\hline & 0 & 0.05 & 0.1 & & Linear & Quadratic \\
\hline \multicolumn{7}{|c|}{ Bodyweight (kg) } \\
\hline Initial & 20.94 & 20.83 & 20.82 & 0.10 & 0.667 & 0.748 \\
\hline Week 4 & 44.07 & 44.18 & 44.19 & 0.25 & 0.092 & 0.364 \\
\hline Week 16 & 111.59 & 111.78 & 112.2 & 0.87 & 0.052 & 0.741 \\
\hline \multicolumn{7}{|l|}{ Week 4} \\
\hline ADG, $g$ & 687 & 711 & 738 & 12 & 0.009 & 0.960 \\
\hline ADFI, $g$ & 1611 & 1619 & 1636 & 20 & 0.372 & 0.853 \\
\hline $\mathrm{G}: \mathrm{F}$ & 0.427 & 0.439 & 0.451 & 0.010 & 0.093 & 0.997 \\
\hline \multicolumn{7}{|l|}{ Week 12} \\
\hline ADG, $g$ & 756 & 748 & 812 & 33 & 0.054 & 0.379 \\
\hline ADFI, g & 1944 & 1973 & 1980 & 12 & 0.248 & 0.481 \\
\hline $\mathrm{G}: \mathrm{F}$ & 0.389 & 0.378 & 0.41 & 0.016 & 0.374 & 0.300 \\
\hline \multicolumn{7}{|l|}{ Week 16} \\
\hline ADG, $\mathrm{g}$ & 794 & 827 & 856 & 22 & 0.063 & 0.941 \\
\hline ADFI, g & 2406 & 2435 & 2411 & 27 & 0.094 & 0.428 \\
\hline $\mathrm{G}: \mathrm{F}$ & 0.33 & 0.341 & 0.355 & 0.011 & 0.119 & 0.886 \\
\hline \multicolumn{7}{|l|}{ Overall } \\
\hline$A D G, g$ & 750 & 761 & 806 & 22 & 0.043 & 0.531 \\
\hline ADFI, $g$ & 2016 & 2039 & 2041 & 12 & 0.152 & 0.456 \\
\hline $\mathrm{G}: \mathrm{F}$ & 0.372 & 0.373 & 0.395 & 0.011 & 0.168 & 0.467 \\
\hline
\end{tabular}

1Standard error of means. Values are represented by 44 pigs per treatment; 4 pigs ( 2 gilts and 2 barrows) per pen; 11 pens per treatment.

in $125 \mathrm{~mm}$ diameter filter paper and pressed for $3 \mathrm{~min}$ at $26^{\circ} \mathrm{C}$. The moisture exposure of the compressed areas was determined using a digitalized area-line sensor (MT10S, M.T. Precision Co. Ltd., Tokyo, Japan). The ratio of water: meat area was then calculated (a smaller ratio indicates increased WHC). Meat sample, $4 \mathrm{~g}$, was sliced and weighed, then the samples were placed in a zipper bag and stored at $4^{\circ} \mathrm{C}$. The samples were weighed on days $1,3,5$, and 7 from the date of sample collection. The initial and the final weight of each sample was used to calculate the drip loss level. Cooking loss was calculated according to the methods of Albercht and others (Albercht et al., 2019).

\section{Statistical analysis}

All data were statistically analyzed using the PROC MIXED procedure of SAS (SAS Inst. Inc., Cary, NC,
USA) in a randomized complete block design. The experimental unit was the pen and the blocks were the sexes. The statistical model for growth performance, nutrient digestibility, and meat quality included effects of dietary treatment as a fixed effect and sex as a random effect. Orthogonal comparisons were conducted using polynomial regression to determine linear and quadratic effects of wood vinegar level on all measurements. Results were considered significant at $P<0.05$ level and $P<0.10$ was considered a trend.

\section{RESULT AND DISCUSSION}

Effects of dietary wood vinegar supplementation on growth performance of grower-finisher pigs were presented in Table 2. The inclusion of dietary wood vinegar supplementation resulted in a trend of linear increase

Table 3. Effects of dietary inclusion of wood vinegar on nutrient digestibility of grower-finisher pigs.

\begin{tabular}{|c|c|c|c|c|c|c|}
\hline \multirow{2}{*}{ Item } & \multicolumn{3}{|c|}{ Wood vinegar (\%) } & \multirow{2}{*}{ S.E.M. ${ }^{1}$} & \multicolumn{2}{|c|}{$P$-value ${ }^{2}$} \\
\hline & 0 & 0.05 & 0.1 & & Linear & Quadratic \\
\hline Dry matter & 694.2 & 712.7 & 724.7 & 0.62 & 0.004 & 0.397 \\
\hline Nitrogen & 687.5 & 711.3 & 723.1 & 0.97 & 0.052 & 0.742 \\
\hline Energy & 705.6 & 717.2 & 725.8 & 0.87 & 0.083 & 0.522 \\
\hline
\end{tabular}

'Standard error of means. Values are represented by 44 pigs per treatment; 4 pigs ( 2 gilts and 2 barrows) per pen; 11 pens per treatments. 
Table 4. Effects of dietary inclusion of wood vinegar on the backfat thickness and lean meat percentage of grower-finisher pigs.

\begin{tabular}{|c|c|c|c|c|c|c|}
\hline \multirow{2}{*}{ Variable } & \multicolumn{3}{|c|}{ Wood vinegar (\%) } & \multirow{2}{*}{ S.E.M. ${ }^{1}$} & \multicolumn{2}{|c|}{$P$-value ${ }^{2}$} \\
\hline & 0 & 0.05 & 0.1 & & Linear & Quadratic \\
\hline \multicolumn{7}{|c|}{ Back-fat thickness, $\mathrm{mm}$} \\
\hline Initial & 10.0 & 9.9 & 9.9 & 0.1 & 0.626 & 0.574 \\
\hline Final & 20.7 & 20.8 & 21.3 & 0.4 & 0.327 & 0.717 \\
\hline \multicolumn{7}{|c|}{ Lean meat, \% } \\
\hline Initial & 63.9 & 63.8 & 64.0 & 0.1 & 0.521 & 0.328 \\
\hline Final & 49.5 & 50.0 & 49.6 & 0.4 & 0.864 & 0.396 \\
\hline
\end{tabular}

IS.E.M. - standard error of the mean. Values are represented by 44 pigs per treatment; 4 pigs ( 2 gilts and 2 barrows) per pen; 11 pens per treatments.

of the BW of pigs at week $4(P=0.092)$ and at week $16(P=0.052)$. In addition, in pigs fed a diet containing wood vinegar supplementation ADG increased linearly during week 4, 12, and during the whole experiment $(P=0.009,0.054$, and 0.043 respectively) and tended to increase $(P=0.063)$ in week 16 . Our finding was consistent with the study of Choi and others (Choi et al., 2009) who observed a higher daily gain in pigs fed graded levels of wood vinegar supplement. Similarly, Wang and others (Wang et al., 2012) stated that feeding weaner pigs with $0.8 \%$ bamboo vinegar had a beneficial effect on growth performance. The dietary inclusion of wood vinegar supplementation failed to affect the ADFI of grower-finisher pigs which was inconsistent with the study of Choi and others (Choi et al., 2009) who observed an increased feed intake in pigs fed a diet containing an increased level of wood vinegar. Similarly, Kook and Kim
(Kook \& Kim, 2003) reported that dietary inclusion of bamboo vinegar increased the feed intake of ducks. Our study revealed that dietary wood vinegar supplementation tended to increase the gain to ratio $(P=0.093)$ in week 4 , which was opposite to the research of Choi and others (Choi et al., 2009) who observed no difference in the feed efficacy in pigs fed a diet containing wood vinegar supplement. We assume that the discrepancies between the findings might be due to the difference in dosage or in animals age. To our knowledge, limited research was presented on the application of wood vinegar in the diet of grower-finisher pigs, thus sufficient comparisons could not be made.

Effects of dietary wood vinegar supplementation on total tract nutrient digestibility of grower-finisher pigs are presented in Table 3 . In pigs fed a diet containing $0.1 \%$ wood vinegar supplementation we observed linearly in-

Table 5. Effects of dietary inclusion of wood vinegar on meat quality traits of grower-finisher pigs.

\begin{tabular}{|c|c|c|c|c|c|c|}
\hline \multirow{2}{*}{ Item } & \multicolumn{3}{|c|}{ Wood vinegar (\%) } & \multirow{2}{*}{ S.E.M. ${ }^{1}$} & \multicolumn{2}{|c|}{$P$-value 2} \\
\hline & 0 & 0.05 & 0.1 & & Linear & Quadratic \\
\hline $\mathrm{pH}$ & 5.32 & 5.40 & 5.27 & 0.06 & 0.567 & 0.171 \\
\hline Longinus muscle area, $\mathrm{cm}^{2}$ & 46.47 & 48.52 & 48.90 & 0.55 & 0.005 & 0.231 \\
\hline \multicolumn{7}{|l|}{ Sensory evaluation } \\
\hline Color & 1.70 & 1.98 & 1.78 & 0.10 & 0.618 & 0.080 \\
\hline Marbling & 1.58 & 1.60 & 1.51 & 0.11 & 0.706 & 0.687 \\
\hline Firmness & 1.74 & 1.91 & 1.81 & 0.09 & 0.574 & 0.241 \\
\hline \multicolumn{7}{|l|}{ Drip loss, \% } \\
\hline Day 1 & 6.29 & 10.93 & 6.95 & 1.08 & 0.669 & 0.004 \\
\hline Day 3 & 9.99 & 13.30 & 12.98 & 1.32 & 0.127 & 0.276 \\
\hline Day 5 & 13.90 & 14.14 & 16.67 & 1.10 & 0.091 & 0.407 \\
\hline Day 7 & 15.12 & 17.23 & 19.68 & 0.94 & 0.069 & 0.013 \\
\hline Water holding capacity, \% & 41.18 & 39.44 & 37.53 & 1.32 & 0.068 & 0.113 \\
\hline \multicolumn{7}{|l|}{ Meat color } \\
\hline $\mathrm{L}$ & 57.96 & 54.73 & 57.69 & 1.06 & 0.858 & 0.027 \\
\hline a & 16.41 & 17.13 & 16.80 & 0.37 & 0.466 & 0.265 \\
\hline$b$ & 8.79 & 9.61 & 9.88 & 0.28 & 0.145 & 0.012 \\
\hline Cook loss $\%$ & 25.31 & 25.13 & 24.86 & 0.73 & 0.670 & 0.961 \\
\hline Carcass weight $(\mathrm{kg})$ & 87.9 & 89.6 & 92.4 & 1.7 & 0.043 & 0.875 \\
\hline
\end{tabular}

1Standard error of means. Values are represented by 44 pigs per treatment; 4 pigs ( 2 gilts and 2 barrows) per pen; 11 pens per treatments. 
creased apparent total digestibility of DM $(P=0.004), \mathrm{N}$ $(P=0.052)$, and a tendency of increased energy $(P=0.083)$ at the end of the experiment, which was not consistent with Rodjan et al. (2018) who observed a reduced $\mathrm{DM}, \mathrm{N}$ and $\mathrm{E}$ in grower-finisher pigs fed diet containing mangosteen wood vinegar supplement. However, in 2009, Choi and others reported that graded levels $(0,0.1$, 0.2 , and $0.3 \%$ ) of wood vinegar in the diet of pigs significantly increased the nutrient digestibility of dry matter, crude protein, and gross energy. Similarly, Yan and others (Yan et al., 2012) pointed out that the use of 0.1 and $0.2 \%$ of bamboo vinegar led to a greater apparent total tract digestibility of dry matter and nitrogen in pigs. Previously, Burnell and others (Burnell et al., 1988) stated that dietary inclusion of wood vinegar enhanced $\mathrm{pH}$ level in gastrointestinal tract thereby reducing the harmful intestinal microflora. From this view, we assume that the increased digestibility might be due to the effect of wood vinegar which balanced the $\mathrm{pH}$ level of the intestinal tract thereby reducing the intestinal microbiota.

Effects of dietary wood vinegar on the backfat thickness and lean meat percentage of grower-finisher pigs are shown in Table 4. Dietary inclusion of wood vinegar supplementation failed to affect the BFT and LMP of grower-finisher pigs. To the best of our knowledge, still, now no experiments have been carried out on the effect of wood vinegar supplementation on the backfat thickness and lean meat percentage, especially in growerfinisher pigs. Thus, adequate comparisons could not be made. Generally, meat $\mathrm{pH}$ is a direct reflection of muscle acid content and it affects sheer force, drip loss and the colour of the meat (Hossain et al., 2015). In 2017, Balasubramanian and others (Balasubramanian et al., 2017)stated that drip loss was used as the main indicator of higher meat quality. However, in this experiment, pigs fed a diet containing $0.1 \%$ wood vinegar supplementation tended to have reduced WHC $(P=0.068)$ and drip loss $(P=0.091$ and 0.069$)$ on $\mathrm{d} 5$ and $\mathrm{d} 7$, respectively. Also, the longissimus muscle area was linearly increased $(P=0.005)$ in the wood vinegar supplementation group compared to the control group. In contrast, Yan and others (Yan et al., 2012) stated that dietary inclusion of bamboo vinegar supplementation had no significant effect on longissimus water holding capacity and TBARS values during the whole experiment. Increased carcass weight is one of the methods of increasing the output and efficiency of meat at the stage of production and processing. Most of the consumers demand leaner meat, but nutritional value increasing carcass weight was associated with an increase in carcass fatness. In this trial, the inclusion of dietary wood vinegar supplementation linearly increased the carcass weight $(P=0.04)$. As observed by Stupka and others (Stupka et al., 2008) increased carcass weight may decrease the lean content and from those findings, we assume that the lack of effects on lean meat percentage may be due to the increased carcass weight. However, apart from WHC, drip loss, longissimus muscle and carcass weight no significant $(P>0.05)$ effects were observed in meat color, sensory evaluation, $\mathrm{pH}$, and cooking loss (Table 5) thus future investigation is needed to optimize the level of wood vinegar in the diet of grower-finisher pigs.

\section{CONCLUSION}

The dietary supplementation of wood vinegar showed a positive impact on the growth performance and apparent total digestibility of grower-finisher pigs. However, the meat quality traits were partially enhanced thus, further research is needed to determine the optimal level of dietary wood vinegar in the diet of grower-finisher pigs that could improve the meat quality for human consumption as well as to optimize the swine production.

\section{Competing interests}

No potential conflict of interest relevant to this article was reported.

\section{REFERENCES}

Albrecht A, Hebel M, Heinemann C, Herbert U, Miskel D, Behnam Saremi, Kreyenschmidt J (2019) Assessment of meat quality and shelf life from broilers fed with different sources and concentrations of methionine. J Food Qual https://doi.org/10.1155/2019/6182580

AOAC (2003) Official Methods of Analysis. Vol. I. 17th edn. Association of Analytical Washington, DC, USA

Bae KH, Ko TG, Kim JH, Cho WT, Han YK, Han IK (1999) Use of metabolically active substances to substitute for antibiotics in finishing pigs. Korean J Anim Sci 41: 23-30

Balamuralikrishnan B, Sang IL, Kim IH (2017) Inclusion of dietary multi-species probiotic on growth performance, nutrient digestibility, meat quality traits, faecal microbiota and diarrhoea score in growing-finishing pigs. Ital J Anim Sci 17: 100-106. https://doi.org/10.1080/1828051X.2017.1340097

Barton MD (2000) Antibiotic use in animal feed and its impact on human health. Nutr Res Rev 13: 279-299. https://doi. org/10.1079/095442200108729106

Burnell TW, Cromwell GL, Staly TS (1988) Effects of dried whey and copper sulfate on the growth responses to organic acid in diets for weanling pigs. J Anim Sci 66: 1100-1108. https://doi.org/10.2527/ jas1988.6651100x

Cai K, Jiang S, Ren C, He Y (2012) Significant damage-rescuing effects of wood vinegar extract in living Caenorbabditis elegans under oxidative stress. J Sci Food Agric 92: 29-36. https://doi.org/10.1002/ jsfa.4624

Cho JH, Min BJ, Kwon OS, Shon KS, Jin YG, Kim HJ, Kim IH (2005) Effects of MSM (Methyl Sulfonyl Methane) supplementation on growth performance and digestibility of CA and $\mathrm{N}$ in pigs. Korean J Food and Nutr 34: 361-365. https://doi.org/10.3746/ jkfn.2005.34.3.361

Choi JY., Shinde PL, Kwon IK., Song YH, Chae BJ (2009) Effect of Wood vinegar on the performance, nutrient digestibility and intestinal microflora in weanling pigs. Asian-Australas J Anim Sci 162: 99-107. https://doi.org/10.5713/ajas.2009.80355

Global Agricultural Information Network. 2011. Korea phases out antibiotic usage in compound feed. [accessed 2017 Feb 2]. http:// gain.fas.usda.gov/Recent $\% 20$ GAIN $\% 20$ Publications /Korea $\% 20$ Phases $\% 20$ Out $\% 20$ Antibiotic\%20Usage $\% 20$ in- $\% 20$ Compoun $\% 20$ Feed_Seoul_Korea $\% 20 \% 20$ Republic $\% 20$ of_7-13-2011.pdf

Hong JW, Kim IH, Kwon OS, Min BJ, Lee WB, Shon KS (2004) Influences of plant extract supplementation on performance and blood characteristics in weaned pigs. Asian-Australas J Anim Sci 17: 374-378. https://doi.org/10.5713/ajas.2012.12170

Hossain MM, Begum M, Kim IH (2015) Effect of Bacillus subtilis, Clostridium butyricum and Lactobacillus acidophilus endospores on growth performance, nutrient digestibility, meat quality, relative organ weight, microbial shedding and excreta noxious gas emission in broilers. Vet Med Czech 60: 77-86

Huang Y, Yoo JS, Kim HJ, Wang Y, Chen YJ, Cho JH, Kim IH (2010) Effects of dietary supplementation with blended essential oils on growth performance, nutrient digestibility, blood profiles and fecal characteristics in weanling pigs. Asian-Australas J Anim Sci 23: 607-613. https://doi.org/10.5713/ajas.2010.80120

Kim PG (1996) Subacute toxicity study of refined wood vinegar. Bulletin of Natural Science Youngin University 1: 35-49

Kook K, Kim JE, Jung KH, Kim JP, Koh HB, Lee JI, Kim CR and Kim KH (2002) Effect of supplemental bamboo vinegar on production and meat quality of meat-type ducks. Kor J Poult Sci 29: 293-300

Mekbungwan A, Yamauchi K, Sakaida T (2004) Intestinal villus histological alterations in piglets fed dietary charcoal powder including wood vinegar compound liquid. Anat Histol Embryol 33: 11-16. https://doi.org/10.1111/j.1439-0264.2004.00501.x

Mohan D, Pittman CU, Steele PH (2006) Pyrolysis of Wood/Biomass for Bio-oil: A Critical Review. Energy Fuels 20: 848-889

NRC. 2012. Nutrient Requirements of Swine, 11th edn. Natl. Acad. Press, Washington, DC.

Rodjan P, Theapparat Y, Khongthong S, Jeenkeawpieam J (2008) Effects of mangosteen wood vinegar as a potential additive on nu- 
trient digestibility in growing pigs. Songkelanakarin I Sci Technol 40: 1002-2008

Roongsitthichai A, Tummaruk P (2014) Importance of backfat thickness to reproductive performance in female pigs. Thai $J$ Vet Med 44: $171-178$

Samanya M, Yamauchi K (2001) Morphological changes of the intestinal villi in chickens fed the dietary charcoal powder including wood vinegar compounds. J Poult Sci 38: 289-301. https://doi. org/10.2141/jpsa.38.289

Sasaki K, Tsunekawa M, Tanaka S, Fudushima M, Konno H (1999) Effect of natural organic acids on microbially mediated dissolution of pyrite in acidic environments. J MMIJ 115: 233-239. https://doi. org/10.2473/shigentosozai.115.233

Stupka R, Cítek J, Sprysl M, Okrouhla M, Kures D, Líkař K (2008) Effect of weight and sex on intramuscular fat amounts in relation to the formation of selected carcass cuts in pigs. Czech J Anim Sci 53: 506-514. https://doi.org/10.17221/366-CJAS
Wang HF, Wang JL, Wang C, Zhang WM, Liu JX, Dai B (2012) Effect of bamboo vinegar as an antibiotic alternative on growth performance and fecal bacterial communities of weaned piglets. Livest Sci 144: 173-180. https://doi.org/10.1016/j.livsci.2011.11.015

Yan L, Kim IH, Huh K (2012) Influence of bamboo vinegar supplementation on growth performance, apparent total tract digestibility, blood characteristics, meat quality, fecal noxious gas content, and fecal microbial concentration in finishing pigs. Livest Sci 144: 240 246. https://doi.org/10.1016/j.livsci.2011.11.020

Yan L, Wang JP, Kim HJ, Meng QW, AO X, Hong SM, Kim IH (2010) Influence of essential oil supplementation and diets with different nutrient densities on growth performance, nutrient digestibility, blood characteristics, meat quality and fecal noxious gas content in grower finisher pigs. Livest Sci 128: 115-122. https://doi. org/10.1016/j.livsci.2009.11.008 